\title{
The Canadian Management of Bovine Spongiform Encephalopathy in Historical and Scientific Perspective, 1990-2014
}

\author{
Alexandra E. Quimby, Michel C.F. Shamy
}

\begin{abstract}
On February 11, 2015, the Canadian Food Inspection Agency announced that a cow born and raised in Alberta had tested positive for bovine spongiform encephalopathy (BSE), commonly known as mad cow disease. BSE is a prion disease of cattle that, when transmitted to humans, produces a fatal neurodegenerative disease known as variant Creutzfeldt-Jakob disease. We believe that this latest case of BSE in Canadian cattle suggests the timeliness of a review of the management of BSE in Canada from a historically and scientifically informed perspective. In this article, we ask: how did the Canadian management of BSE between 1990 and 2014 engage with the contemporary understanding of BSE's human health implications? We propose that Canadian policies largely ignored the implicit medical nature of BSE, treating it as a purely agricultural and veterinary issue. In this way, policies to protect Canadians were often delayed and incomplete, in a manner disturbingly reminiscent of Britain's failed management of BSE. Despite assurances to the contrary, it is premature to conclude that BSE (and with it the risk of variant Creutzfeldt-Jakob disease) is a thing of Canada's past: BSE remains very much an issue in Canada's present.
\end{abstract}

RÉSUMÉ: Perspective historique et scientifique sur la gestion de l'encéphalopathie spongiforme bovine au Canada de 1990 à 2014 . Le 11 février 2015 l'Agence canadienne d'inspection des aliments a annoncé que le test de dépistage de l'encéphalopathie spongiforme bovine (ESB), communément appelée maladie de la vache folle, s'était avéré positif chez une vache née et élevée en Alberta. L'ESB est une maladie à prion chez les bovins qui, quand elle est transmise aux humains, cause une maladie neurodégénérative fatale connue sous le nom de variante de la maladie de Creutzfeldt-Jakob. Nous croyons que ce cas récent d'ESB chez une vache canadienne indique qu'il est temps de revoir la gestion de l'ESB au Canada sous un éclairage historique et scientifique. Dans cet article, nous posons la question suivante : comment la gestion de l'ESB au Canada de 1990 à 2014 s'est-elle adaptée aux connaissances actuelles des répercussions de l'ESB sur la santé humaine? Nous suggérons que les politiques canadiennes ont ignoré dans une large mesure la nature médicale inhérente à l'ESB en la traitant comme un problème purement du domaine de l'agriculture et du domaine vétérinaire. Souvent les politiques destinées à protéger les Canadiens ont donc été tardives et incomplètes, rappelant de façon préoccupante l'échec de la Grande-Bretagne à gérer l'ESB. En dépit d'affirmations contraires, il est prématuré de conclure que l'ESB (et ainsi le risque de contracter la variante de la maladie de CreutzfeldtJakob) est chose du passé au Canada : l'ESB y demeure un problème actuel.

Keywords: Creutzfeldt-Jakob Disease, Healther Services Research, History, Neurosciences, Prion doi:10.1017/cjn.2015.286

Can J Neurol Sci. 2015; 42: 472-481

On February 11, 2015, the Canadian Food Inspection Agency (CFIA) announced that a cow born and raised in Alberta had tested positive for bovine spongiform encephalopathy (BSE), commonly known as mad cow disease. ${ }^{1}$ BSE was first recognized in England in the 1980s, where exposure was eventually identified as the cause of a fatal neurodegenerative disease of humans known as new variant Creutzfeldt-Jakob disease (vCJD). ${ }^{2}$ This new case of BSE in Canada reflects the first since 2011, and the first in a cow born since the implementation of Canada's current BSE control measures in 2007. In his official remarks to the press, Canadian Minister of Agriculture Gerry Ritz announced that this single case of BSE should not significantly impact the economic viability of the Canadian cattle industry. ${ }^{3}$ However, Ritz made no mention of the human health ramifications of BSE, nor of the implications of this new case on prior assurances of the efficacy of Canada's BSE policies.

This latest case suggests the timeliness of a review of the landscape of BSE in Canada from a historically and scientifically informed perspective. The history of BSE in Britain is widely known in medical circles, though the narrative of BSE in Canada has received significantly less attention in the medical literature. The British and Canadian experiences with BSE are distinct, and they tell complementary stories about government regulation in the face of evolving medical science. When BSE was first identified in Britain in 1984, its management was dominated by uncertainty surrounding a set of fundamental questions: how had it arisen, would it be transmissible to humans, and what measures would best control its spread ${ }^{4}$ By the time the first

From the Faculty of Medicine, University of Ottawa, Ottawa, Ontario, Canada (AEQ); Department of Medicine (Neurology), University of Ottawa, Ottawa, Ontario, Canada (MCFS).

Received December 12, 2014. Final Revisions Submitted June 19, 2015. Correspondence to: Michel Shamy, 1053 Carling Avenue, Room C2182a, Ottawa, ON K1Y 4E9, Canada.Email: mshamy@toh.on.ca. 
Canadian-born cow tested positive for BSE in 2003, much of that uncertainty had been addressed.

Therefore, we propose to analyze Canada's management of BSE in light of the state of knowledge surrounding BSE that developed in the aftermath of the British experience. In this article, we ask: how did the Canadian management of BSE during the years 1990-2014 engage with the contemporary understanding of BSE's human health implications? We propose that Canadian policies largely ignored the implicit medical implications of BSE, treating it as an agricultural and veterinary issue. In this way, policies to protect Canadians were often delayed and incomplete, in a manner disturbingly reminiscent of the failed British experience.

BSE presents somewhat different challenges to other foodborne illnesses and public health concerns. Unlike other foodborne infections (e.g. Escherichia coli, Salmonella), exposure to BSE does not induce immediate symptoms, but rather may incubate for years or decades. Therefore, the association of exposure to outcome cannot be done by frontline clinicians, but rather requires the maintenance of information systems over time and space. This type of data collection involving agricultural and public health elements would appear to require governmental involvement. Because BSE is contracted unintentionally and unknowingly, it is different from other public health matters such as cigarette smoking or alcohol abuse, where exposure occurs with (at least some) knowledge of doing so and with (at least some) comprehension of the adverse impact on health. Though smoking or alcohol abuse undoubtedly produces a higher burden of disease at the population level than did vCJD, they do so through incremental and long-term exposure; exposure to BSE is potentially fatal, even at very small doses. ${ }^{5}$

Because of these factors, the appearance of BSE in Great Britain in the 1980s, and its subsequent transmission to humans in the form of VCJD in the 1990s, retains the flavor of a horror story. A previously unknown disease, universally fatal, was inadvertently contracted by hundreds of young people through exposure to a pathogen contained within their diet. And yet, scientific understanding of BSE grew rapidly over a very short period, sufficient to develop highly effective control measures within a decade. Because of the nature of the transmissibility of BSE, the complex nature of agricultural regulatory policy, and the potential success of well-administered public health measures, governments are uniquely positioned to protect their citizens from BSE and vCJD, and as a consequence bear significant responsibility for the management of BSE.

An extensive body of literature has dissected the British experience with BSE ${ }^{6-10}$ most notably in the form of a 1000-page government report published in 2000. ${ }^{11}$ The BSE crisis has been widely recognized as a complex event with veterinary, agricultural, industrial, political, and public health dimensions. Appropriately, the story of BSE can (and has) been told through several different lenses: political, economic, medical, and historical. The developing scientific narrative surrounding BSE and vCJD was captured in leading medical journals of the 1990s, serving both as a historical chronicle and locus of debate. ${ }^{12,13}$ The British BSE experience has been historically contextualized, most notably in the work of acclaimed veterinary historian Abigail Woods. ${ }^{14,15}$ Contemporary policy analysis has focused largely on the concept of risk: its assessment, management, and communication. ${ }^{16,17} \mathrm{~A}$ variation of this risk-based approach has applied the perspective of the "precautionary principle," which seeks to guide public policy in settings of uncertain risk by placing the burden of proof on those who argue against precautionary measures. ${ }^{18}$

A smaller though still substantial body of research has probed Canada's management of BSE. Interestingly, relatively little of this analysis has appeared in the Canadian medical literature. ${ }^{19,20}$ The majority of the scholarship on BSE in Canada has evolved from policy and economic perspectives, often with little consideration $^{21-23}$ or limited understanding ${ }^{24,25}$ of its public health implications. For example, a 2004 Senate report on BSE made no mention of human health at all, instead focusing on "havoc in the beef industry.",26

This intellectual landscape likely reflects a fundamental difference between the Canadian and British experiences with BSE: namely, that there have been 122 confirmed cases of vCJD in Britain as of $2014,{ }^{27}$ whereas no cases of vCJD have been acquired in Canada. Therefore, a strong impetus exists to consider the Canadian management of BSE a purely agricultural and industrial issue, and a success from the perspective of public health policy. However, the absence of vCJD cases among Canadian-born citizens need not be taken as an indication that the risk of BSE has been controlled or that Canadians were adequately protected from BSE during the highest risk period. As American policy analysts Joseph Aldy and Kip Viscusi have argued, that BSE was less of a public health disaster in Canada than it had been in Britain does not necessarily mean that it was well-managed. ${ }^{28}$

Our analysis of the Canadian experience with BSE is particularly influenced by the work of British social scientist David Miller, who uses the example of BSE in Britain to argue that "there is no apolitical way of extracting science." ${ }^{, 29}$ Miller proposes that the natural biases and underlying assumptions of decision-makers and institutions influence the way scientific knowledge is interpreted and applied. From this perspective, analysis of the Canadian experience must be sensitive to the biases and beliefs of stakeholders and to the distribution of decisionmaking power. As Miller cautions, "There is no straightforward way of taking decisions, but there is a way of operating with transparency and without secrecy... there is a way of making assumptions explicit." ${ }^{29}$ Miller's analysis of BSE in Britain comes from a background in media studies and political science; therefore, he engages with how science is used but not necessarily with the science itself. We hope to go beyond this limitation by integrating the historical and political aspects of the Canadian BSE experience in light of contemporary neurological and medical understanding.

We believe that the Canadian management of BSE remains a topic of importance to Canadians and to Canadian neurologists. Neurologists were involved in caring for patients suffering from vCJD in Britain, France, and around the world. Were vCJD to reappear, neurologists would likely be the frontline physicians engaged in the diagnosis and treatment of afflicted patients. Moreover, understanding the political management of BSE may be particularly important for physicians in this era of resurgent and emerging diseases. The management of BSE can also be understood as an example of the engagement of Canadian policymakers with matters of evolving scientific knowledge. Finally, although political and medical officials have generally concluded that BSE no longer poses a major public health concern in Canada, a more nuanced perspective on this matter may lead to differing conclusions and a more sober response to Canada's latest case of BSE. 
Although the focus of this article is on the Canadian management of BSE, we begin by reviewing the science of BSE as it has come to be understood over the past three decades, and by exploring some of the major themes of the British BSE experience. From these historical and scientific contexts, we analyze and interpret Canada's response to BSE. Our methodology is therefore mixed, in that we refer to primary sources in the medical literature, first-hand accounts in the public press, and government documents issued in Britain and Canada. Additionally, we have grounded our argumentation in the work of other national and international experts on BSE and its management in order to generate a detailed picture of the BSE experience in Canada.

\section{The SCIEnCE OF BSE}

BSE and vCJD are today classified as transmissible spongiform encephalopathies (TSEs), which are understood as rapidly progressive and fatal brain diseases affecting several mammalian species. ${ }^{30}$ The oldest known TSE is scrapie, a disease of sheep first identified in the 18th century. Beginning in the 1980s, American neuroscientist Stanley Prusiner had argued for the causal role of the prion protein in the TSEs, rather than the "slow viruses" that had been implicated for much of the 20th century. The prion occurs naturally in the central nervous system of many species, performing an as-yet unspecified function. Prusiner argued that TSEs arise when the prion obtains a misfolded shape that is then transmissible to other prions. ${ }^{31}$ Through this mechanism, TSEs can be spread between individuals and across the species barrier. Despite facing much opposition, Prusiner's theory was ultimately proven right, and he was awarded the 1997 Nobel Prize for Physiology or Medicine at the height of the British BSE crisis.

At the pathological level, prion diseases are associated with the aggregation of an abnormal prion protein (termed PrPSc) in the brains, spinal cords, and lymphoreticular tissue of affected individuals. These PrPSc particles appear resistant to common decontamination procedures. The aggregates of misfolded protein seen in many TSEs, including Creutzfeldt-Jakob disease (CJD) and $\mathrm{vCJD}$, bear a certain resemblance to the proteinaceous inclusions found in Alzheimer's disease. ${ }^{32}$ Following the BSE crisis, this similarity was used to support a hypothesis linking beef consumption to the development of Alzheimer's disease. ${ }^{33}$ However, a lack of concrete evidence and several notable differences between the diseases has led to the ultimate dismissal of this notion. $^{34,35}$

The most common human TSE is CJD, occurring with an incidence of approximately 1 per million per year. CJD was first described in the 1920s by German neuroscientists Hans Gerhard Creutzfeldt and Alphons Maria Jakob. Mean survival is 4-8 months; $90 \%$ of patients are dead within 1 year. The peak age of onset is $55-75$ years. The diagnosis is firmly established through autopsy, though characteristic changes on magnetic resonance imaging scan and electroencephalography are highly sensitive and specific. ${ }^{36}$ CJD may arise in a familial or sporadic pattern, and is now understood to reflect patients' genetic variability. Hereditary and sporadic CJD reflect mutations at codon 129 in the prion protein $_{\text {gene. }}{ }^{31}$ Similarly, it appears that sensitivity to BSE exposure reflects homozygosity for methionine at codon 129 of the host's prion protein gene, in that all cases of vCJD have demonstrated this genotypic pattern. ${ }^{37}$
Beginning in 1993, a new clinical syndrome reminiscent of CJD was identified among young people in Britain. ${ }^{12}$ This syndrome was later named VCJD, and is characterized by prominent behavioral features, ataxia, dementia, and ultimately death. The age of onset of vCJD is much younger than classical CJD, typically affecting those in their teens and 20s. The course of vCJD is relatively prolonged, with death occurring after a mean of 14 months. Diagnostic findings of vCJD on magnetic resonance imaging and electroencephalography are distinct from CJD. ${ }^{36}$ As of 2014, there have been 229 cases of vCJD worldwide, mostly in the United Kingdom; two cases have been reported in Canada. ${ }^{38}$ It is now understood that $\mathrm{VCJD}$ reflects the transmission of BSE to humans via the consumption of infected beef. ${ }^{13,39-43}$

\section{BSE AND VCJD IN BRITAIN, 1984-1996}

The origins of the BSE crisis in Britain have been traced to Sussex in December 1984, when a cow fell ill with a new clinical syndrome: tremor and incoordination rapidly leading to death. Within a few months, cows from all across Britain had succumbed to a similar constellation of symptoms. The total number of cows affected in Britain likely exceeded 1 million. ${ }^{11}$ The rapid spread of BSE across the country is now attributed to the agricultural system of rendering, in which protein is extracted from nonmuscular sources called offal, and is then incorporated into human or animal food as meat and bone meal (MBM). Although it is unclear how BSE first arose in Britain's cattle, a strong body of evidence suggests that the rendering of affected cattle allowed for the dissemination of infected MBM across Britain. In essence, cow protein containing BSE was fed back to cows, cannibalizing a herbivorous species and creating an ideal route of transmission for a prion disease. ${ }^{2}$

The first official pathological analysis of cattle with BSE was produced in 1986 by Raymond Bradley of England's Central Veterinary Laboratory. Bradley characterized the features of BSE as sharing "similarities to spongiform encephalopathies of other species and in particular scrapie of sheep." ${ }^{11}$ As demonstrated by his initial report and by subsequent British policy decisions, the significance of the discovery of this new disease was immediately apparent. In that initial report, Bradley wrote:

If the disease turned out to be bovine scrapie it would have severe repercussions to the export trade and possibly also for humans if for example it was discovered that humans with spongiform encephalopathies had close association with the cattle. It is for these reasons I have classified this document confidential...

At present I would recommend playing at low key because a simple explanation may be forthcoming as a result of current investigations which will allay fears.

You may also find the information valuable for defence of the [Central Veterinary Laboratory] in a political sense. ${ }^{11}$

Bradley's report, the first government document discussing a spongiform encephalopathy of cattle, exemplifies a set of interwoven themes that came to dominate the story of BSE in Britain. ${ }^{4}$ BSE was assumed to reflect the spread of scrapie to cattle, and therefore it was not expected to be transmissible to humans. As a 
consequence, animal health experts, and not medical professionals, directed the management of BSE in Britain. And although the potential significance of BSE for human health was immediately apparent, medical concerns were considered secondary to BSE's immediate economic and political ramifications.

Because BSE was thought to reflect the infection of cattle with scrapie, which had never been known to cross the species barrier, scientists and policymakers repeatedly stated that BSE would pose no risk to humans. ${ }^{11}$ This conclusion was questioned scientifically as early as 1990, when pathological analyses demonstrated different histological properties and patterns of transmission for BSE and scrapie. However, the association between BSE and scrapie was not officially tested by scientists at Britain's Ministry of Agriculture, Fisheries and Food (MAFF) until 1996. In March 1996, the Secretary of State for Health, Stephen Dorrell, announced to Parliament the results of investigations performed by a separate group of physicians and epidemiologists who had concluded that the first cases of vCJD reflected the transmission of BSE to humans. $^{44}$

Despite denying the existence of a risk to humans up until 1996, British policies implicitly recognized that human infection was a possibility. ${ }^{29}$ In fact, the British government's continued assurances undermined the implementation of its own policies. ${ }^{16}$ For example, a series of measures were put in place between 1988 and 1990 to limit exposure to the highest risk tissues from infected cattle, what British agencies termed specified bovine offal (SBO). Though legislation banned SBO from human consumption in June 1989, cattle farmers were given 5 months to dispense of their stock into the human food chain. Surveillance was difficult, and penalties for including SBO in processed meats were minimal. In March 1995, surveillance by MAFF veterinarians found that $48 \%$ of abattoirs and slaughterhouses were not fully complying with regulations to keep SBO out of human foodstuffs. ${ }^{45}$ Ultimately, slaughterhouses did not feel compelled to exclude SBO from processing because the government had repeatedly reassured the nation that BSE would pose no risk to humans.

The inconsistencies and contradictions inherent in the British government's policies reflect a state of scientific uncertainty superimposed upon an administrative structure that was biased toward the interests of the cattle industry. ${ }^{29}$ Miller has argued that risk disputes like those surrounding BSE "are disputes over matters of interests and the distribution of resources... ideology is the crucial attendant of such controversies." ${ }^{29}$ MAFF was charged with both maintaining food safety and advocating for the agricultural industries, two tasks that were in conflict during the BSE era. Following the election of Margaret Thatcher's Conservative government in 1979, MAFF had advocated for free market practices and industrial self-regulation within the agricultural sector, which arguably had contributed to the rise of BSE and had certainly impacted its management. ${ }^{18}$ For example, MAFF sought to prevent panic surrounding BSE, a goal it achieved by banning the publication of information about BSE for 6 months after its initial description. ${ }^{46}$ Government officials could not speak to the media about BSE without first seeking approval from MAFF. All BSE-tested cattle brains became MAFF property and were withheld from independent researchers. ${ }^{18}$

Critics of Britain's management of BSE have argued that from 1986 to 1996 the government failed at assessing, managing, and communicating the (as-yet uncertain) risks posed by BSE for the people of Britain. ${ }^{46}$ In light of these conclusions, the Canadian experience with BSE can serve as an important contrast to British management, with relevance for Canadians but also for governments around the world. How did Canada's policies reflect the improved state of knowledge within the scientific community in the early 2000s? How did Canada balance private and public interests in its handling of BSE? In short, did Canada improve on British policies or replicate its mistakes?

\section{BSE AND VCJD IN CANADA, 1990-2014}

As in Britain, Canada's experience with BSE can be analyzed from the perspective of risk assessment, management, and communication. ${ }^{47}$ In this article, we are most interested in the way risk assessment was implicitly reflected in management and communication decisions. In the aftermath of the British experience, we are sensitive to the way risk assessment expressed in official government statements and documentation may not reflect the logic of enacted policies or vice versa. Importantly, analysis of risk assessment and management needs to be appropriately historicized: namely, policies and practices are most fairly understood in reference to the state of knowledge in their time and place.

The world learned of BSE as a cattle disease in the late 1980s, and its meaning for public health (suggested as early as 1986) became clear by 1996. Therefore, for most of the period in question here, BSE was known to be a disease of cattle that could be transmitted to humans with devastating consequences. Uncertainty surrounding the question of whether BSE could cause human disease was, as of 1996, no longer justifiable: a series of experiments conducted in cattle, sheep, cats, and humans had demonstrated that BSE and VCJD were pathologically identical to each other and distinct from other TSEs. ${ }^{48}$ Therefore, claims that the discovery of BSE in Canadian cattle "created unmanageable uncertainty" 49 must be reframed: the discovery of BSE in Canada established with certainty that a previously theoretical public health risk was now present in Canada and would have to be addressed appropriately. We contend that this did not occur, in that the Canadian government appears to have failed to appreciate the implicit public health implications of BSE. Policies were delayed and incomplete in their implementation, biased toward the beef industry thereby placing human health in danger. That this danger has not been reflected in human disease is gratifying but should not be seen as proof positive of effective policies.

Canada's management of BSE began in 1990, when it made BSE a reportable disease. ${ }^{50}$ Though no cases of BSE were known to exist in Canada at that time, reportable status meant that any cow diagnosed with BSE would be required to be withheld from the food supply and reported to government agencies. The identification of BSE as a reportable disease at this stage reflected an appropriate level of concern on behalf of federal regulators; should BSE be found in Canada, it would justifiably be an issue to be addressed by governmental agencies. The responsibility for BSE surveillance and testing was eventually centralized under the auspices of the CFIA in 1997.

Canada's surveillance program is, and was from its outset, voluntary, or "passive" in that diagnostic testing is only initiated if BSE is suspected on clinical grounds. At no point did Canada require random testing for BSE as exists in Japan, nor has there been routine testing of cattle above a certain age, as is done in the European Union. ${ }^{17}$ Therefore, for a Canadian cow to be tested, its 


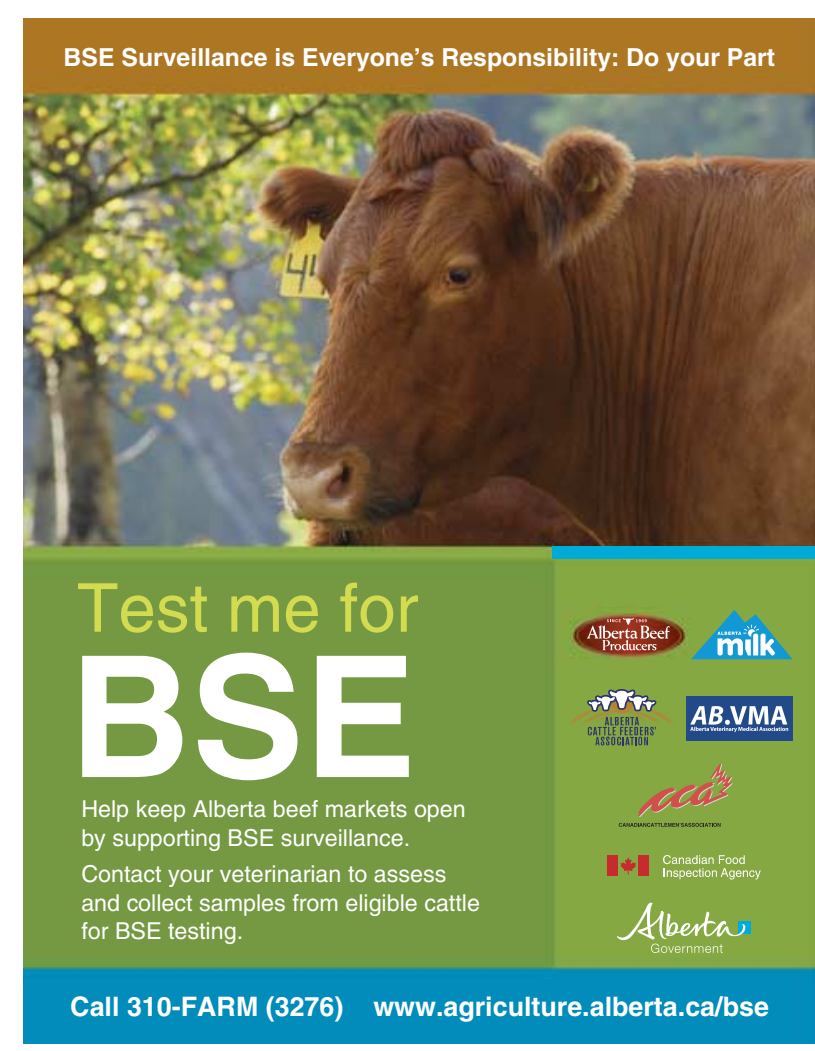

Figure 1: Test me for BSE. Image courtesy of Agriculture Alberta. Accessed online at: http://wwwl.agric.gov.ab.ca/\$Department/ deptdocs.nsf/All/cpv15105

owner would need to identify one of a certain set of agreed-upon clinical features that may point to BSE. Specifically, tested cattle are those that are found dead, seem to be diseased or dying, or "downers," meaning that they can no longer stand. The owner must then alert a local veterinarian to obtain a sample of the cow's brain, thereby killing the cow. During the period of testingwhich now takes only days- the cattle would have to be stored and eventually disposed of. Canada tests approximately 30,000 cattle per year, a number in accordance with guidelines established by the World Organization for Animal Health (OIE) on the basis of Canada's cattle population. ${ }^{51,52}$

The logistics of BSE testing are important and continue to reflect a major source of controversy in Canada. We propose that the Canadian surveillance system for BSE is biased against testing, a circumstance that echoes the British experience. Although cattle farmers are provided compensation if a cow is found positive for BSE, ${ }^{53}$ the act of testing still risks a financial loss for producers and processors. ${ }^{54,55}$ Cattle producers report significant stigma associated with the reporting BSE-positive cattle. ${ }^{56}$ The Canadian Cattlemen's Association continues to engage in public relations campaigns encouraging testing, ${ }^{57}$ which demonstrates the tendency against testing in the industry (see Figure 1). Moreover, in private communication with the Canadian Cattlemen's Association, we were informed that rates of testing appear to fluctuate with the market value of cattle (personal communication with Rob McNabb, December 3, 2014). This observation suggests the impact of the economic disincentives built into the Canadian surveillance system: when the auction value of the cow is highest, the loss produced by sending it for testing is greatest, and

therefore the impetus to test is at its nadir. Therefore, cattle that would meet the criteria for testing may not always be sent for testing, indicating how an already passive system ${ }^{58}$ remains porous to potentially affected animals.

Though the CFIA notes that its protocols are in accordance with guidelines set by the OIE, this assertion is not entirely true. When the OIE performed a review of Canada's management of BSE in 2004, it suggested the implementation of an expanded surveillance protocol that would include non-cattle from farms at risk, a suggestion that was never adopted by the CFIA. ${ }^{59}$ A 2004 report by the Attorney General of Ontario addressing issues of meat safety argued for the use of both passive and active (i.e. routine) surveillance to ensure a comprehensive risk management system. ${ }^{47}$ Furthermore, although the numbers of cattle tested are in accordance with the OIE, there is ultimately no penalty for not reaching those targets. Moreover, because Canada has never performed routine surveillance to establish an accurate incidence of BSE among its cattle herds, it is difficult to know whether the targets suggested by the OIE on the basis of herd size are appropriate for the Canadian population. Finally, there is currently no way of knowing whether the right cattle are being tested, by which we mean that cattle with BSE may be voluntarily or involuntarily excluded from testing. ${ }^{51,56}$ Therefore, subclinically affected cattle may still be reaching the slaughterhouse.

The first cow to test positive for BSE was discovered in Alberta in 1993. This cow had been imported from Britain in 1987, a practice Canada later banned in $1990 .{ }^{28}$ Canada's first BSE-infected cow was slaughtered, along with its herd mates and all other cattle that had been imported from the United Kingdom after 1982. The year 1982 was selected in light of a set of assumptions that had informed British policies about the origins of BSE - namely, that the BSE crisis had started in 1987, and that BSE's incubation period would be no longer than 5 years. However, these assumptions were already in question by the early 1990s and were subsequently rejected after more extensive research. ${ }^{4}$ Ultimately, slaughtering older cattle would have had little impact because cattle imported from Britain before 1982 would likely have already entered the food chain by 1990 . However, the point to be made is that Canada's culling policies were based on scientific data that were already out of date.

Canada's response to the first case of BSE within its borders focused on minimizing "external challenge" (i.e. the spread of BSE to Canadian herds from imported cattle) while failing to consider "internal challenge" (i.e. the possibility that BSE existed in, or might later arise from, native Canadian cattle). ${ }^{17}$ Policies assumed that Canada's BSE-infected cow had acquired the disease in Britain and that BSE could not be spread to other cattle. As a consequence, further risk management measures (such as enhanced surveillance or stricter controls on rendering) were believed unnecessary. Though the causal role of rendering in the spread of BSE was strongly suspected by $1993,{ }^{60}$ this practice continued unabated in Canada.

In May 1994, the Animal, Plant, and Food Risk Analysis Network (APFRAN), a division of the CFIA, completed a formal risk assessment of BSE in Canadian domestic herds. ${ }^{22}$ APFRAN's 1994 report echoed the early years of the British BSE crisis, in that it predicted that the economic impact of any indigenous cases of BSE would be "high." 23 This analysis was reminiscent of the 1986 report by British pathologist Raymond 
Bradley, in which he had stated that a BSE "would have severe repercussions to the export trade and possibly also for humans." To limit panic, Bradley had suggested that his report be kept confidential. ${ }^{11}$ Similarly, APFRAN's 1994 report on BSE in Canada was withheld from the public and was only discovered by journalists through an Access to Information request in 2001.

The APFRAN report explicitly considered the possibility that BSE might have been disseminated into Canadian cattle feed through rendering, as had occurred in Britain. This is significant for two reasons: first, the APFRAN report went beyond the government's stance in considering BSE an "external" threat and accepted it now as an "internal" issue; second, it demonstrates that Canadian scientists were aware of the role of rendering in the spread of BSE at least as early as $1994 .^{22}$ Restrictions on rendering at this early stage might have represented an important step in limiting any potential dissemination of BSE among Canadianborn cattle. Ultimately, the rendering of cattle continued in Canada until 1997, when the human health implications of BSE in Britain became a political issue that the federal government could no longer ignore. The notoriety of the BSE crisis in Britain, and its link to vCJD, prompted the Canadian government to impose a ban on the feeding of ruminant tissues to other ruminants. In this way, we see Canadian policy responding to the novel scientific landscape produced by the assured association between BSE and vCJD, though the role of rendering in the spread of BSE, and the presence of BSE in Canada, had been known years earlier.

Canada's 1997 ban on the use of rendered cattle as meat and bone meal in cattle feed was an inadequate risk control measure, in that MBM continued to be used in the feed of poultry, pork, and domestic animals. ${ }^{61}$ Because cattle could still be fed to other livestock, and other livestock could still be fed to cattle, an indirect means for the transmission of BSE among cattle remained. In addition, no surveillance existed to prevent crosscontamination at feed mills. Moreover, Canada's 1997 ban allowed for the continued use of existing feed stock, recalling British policies that had allowed farmers to use up feed stock after their equivalent ban a decade earlier. ${ }^{17}$ Albeit arbitrary, once a particular product has been deemed a risk, continued exposure becomes difficult to justify from a political and public health perspective.

In 2002, the CFIA carried out a more extensive risk assessment on the question of BSE in Canada. The CFIA report concluded that the 1997 MBM ban had resulted in a "negligible probability" that BSE had taken hold in Canada. However, the CFIA also commented that, should this assessment be proven incorrect, the consequences would be severe. ${ }^{62}$ As in Britain, the "consequences" with which the CFIA was concerned were political and economic in nature, with only one oblique reference to human health. The language of the CFIA report again implied that BSE, were it to arise, would be an "external" threat, and that spontaneous BSE would not be expected to occur among Canadian cattle.

In May 2003, 2 months before the CFIA report was published, the first native Canadian case of BSE was discovered. In response, 2700 herds of cattle were slaughtered. ${ }^{22}$ Compounded by the discovery of an Alberta-born, BSE-infected cow in Washington state, the Canada-United States border was closed to Canadian beef exports. Thirty-three other countries subsequently banned live cattle and beef products from Canada. Economic damage to the Canadian cattle industry was on the order of $\$ 11$ million per day, totaling $\$ 5.5$ billion over 4 years. ${ }^{63}$ Prompted by

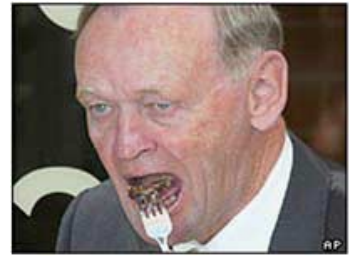

Figure 2: Prime Minister Chrétien eating steak in the midst of Canada's BSE crisis. Image courtesy BBC website (http://news.bbc.co. uk/2/hi/americas/3050455.stm).

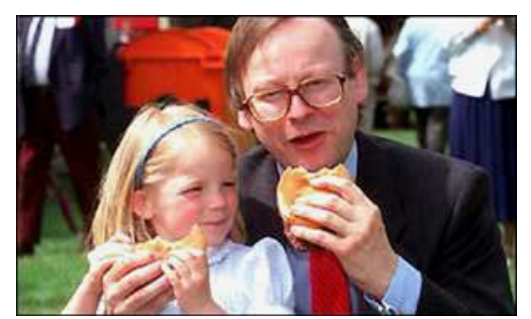

Figure 3: British Agriculture Minister John Gummer and his daughter eat hamburgers during the British BSE crisis. Image courtesy BBC website (http://news.bbc.co.uk/2/hi/uk_news/369625.stm).

economic rather than by health concerns, the Canadian government channeled $\$ 460$ million to cattle producers through various federal and provincial programs and began offering compensation for the slaughter of cows. Compensation was determined on a sliding scale, to a maximum of $\$ 320$ per animal, approximately one-quarter of previous market value. ${ }^{64}$ As in Britain (where farmers were provided $50 \%$ of the value of animals), low rates of compensation gave farmers little incentive to report and slaughter potentially affected animals. ${ }^{16}$ Officials and politicians promoted the safety of Canadian beef, despite the absence of evidence to support such claims. The likelihood of finding additional infected cows in Canada was declared "insignificant," until new cases arose. ${ }^{58}$ Since 2003, an additional 19 cases of BSE have been discovered in Canadian-born cattle, with the most recent case identified in February 2015. Assertions that cows could not develop the disease if they were younger than 30 months of age were also proven incorrect. As in Britain, the Canadian public was repeatedly reassured that the government had the situation under control. ${ }^{64}$ Prominent government figures made a show of eating beef, including then-Prime Minister Jean Chrétien. Thirteen years earlier, British Agriculture Minister John Gummer had famously appeared on television at the height of Britain's BSE crisis to feed his daughter a hamburger (see Figures 2 and 3). ${ }^{65,66}$

In response to the discovery of the two BSE-infected Canadian-born cattle, all specified risk materials (SRM) - those tissues most likely to contain BSE such as brains, spinal cords, and distal ileum-were prohibited from entering the human food chain. ${ }^{17,67}$ Before 2003, the government had considered Canada to be "BSE-free," despite the discovery of a BSE-positive cow ten years earlier, and despite available knowledge about the role of rendering in BSE's transmission. From 1990 to 2003, only the SRM from the one cattle with diagnosed BSE had been excluded from processing, allowing SRM from infected but asymptomatic, or simply untested, cattle to have entered the human food supply. The prohibition of all SRM from entering the food chain was enacted in 2003 as an attempt to guarantee that BSE could not pass 
to humans. Organs that had the potential to harbor BSE, even from potentially yet undiagnosed cattle, would therefore be excluded from consumption.

The Canadian ban on SRM parallels the British measure to remove all SBO from the human food chain, a decision that had been taken in Britain in June 1989. As in Britain, this prohibition was introduced without immediate effect, allowing cattle producers to continue to use SRMs in the human food chain for a further month after the ban was announced. Assessment regarding compliance with this legislation is performed by the CFIA in the form of quarterly random checks at slaughterhouses. According to the CFIA, no Canadian facility has ever been found to be in contravention of this order (personal communication with Dr. Noel Murray, December 3, 2014), in stark contrast to the British and American experiences, where up to $50 \%$ of slaughterhouses were found to be noncompliant with similar requirements. ${ }^{28}$

Four years later, in 2007, Canada instituted an enhanced feed ban, prohibiting the inclusion of ruminant materials (essentially, rendered cattle) in any form of animal feed. ${ }^{68}$ Although ruminant materials had been excluded from ruminant feed in 1997, for ten years the government had allowed the use of ruminant materials in feed for chickens, pigs, fish, and domestic animals. The production of some feed with ruminant parts, and some without, creates an environment for potential cross-contamination between different pools of feed. Moreover, other animals exposed to ruminant-containing feed could become a reservoir for BSE infection and cross-transmission. As early as 1990, domestic cats in Britain had been diagnosed with BSE presumably acquired from eating feed contaminated with cattle SRM. ${ }^{46}$ Canada has no reported cases of BSE in non-cattle, but it is not testing for them because BSE surveillance measures do not include non-cattle. ${ }^{58}$

No cases of vCJD have been linked to exposure to BSE in Canada, though two patients with vCJD have been treated in Canada since 1990. The first case of vCJD was identified in 2002 in a patient who had immigrated to Canada from the United Kingdom in the early 1990s. It was assumed that he had contracted vCJD there and had only begun to exhibit symptoms after arrival in Canada because of the disease's long incubation period. ${ }^{69}$ The second case occurred in 2011 in a patient who had immigrated from Saudi Arabia and had reportedly begun to exhibit symptoms before his immigration to Canada. The Public Health Agency of Canada has therefore concluded that the incidents have "no negative implications for the safety of the Canadian food supply" and "no secondary risks to the health of Canadians." 69 In addition, the Canadian government has enacted various policy measures to prevent the disease-causing prion protein from entering the Canadian blood supply. Most notably, these included the 1999 and 2000 deferrals of blood donations from individuals having visited the United Kingdom and France during the height of these regions' BSE crises. ${ }^{70}$ Demonstration of the prion protein in human lymphoreticular tissue before the onset of symptoms in individuals infected with vCJD raises the potential for disease transmission in this manner. ${ }^{71}$ However, an ongoing study has not been able to demonstrate blood transfusion as a cause for vCJD development in any individuals who have succumbed to the disease in Canada or elsewhere. ${ }^{72}$

\section{CONCLUSIONS}

When the British government was confronted with the rise of BSE in the late 1980s, its policies were necessarily based on rudimentary scientific knowledge. Despite allowances for this uncertainty, British management of the BSE crisis has been almost universally criticized for its secrecy, deference to industrial interests, and unwillingness to reconsider assumptions. ${ }^{46}$ By the late 1990s, much more was known about the origins and transmission of BSE, and it is in light of this advanced science that Canadian policies should be evaluated. The lack of Canadianacquired cases of vCJD might suggest that Canada's management of BSE was successful. Canadian BSE experts have argued as recently as December 2014 that the absence of BSE in any cattle born after 2007 demonstrates the efficacy of current federal policies (personal communication with Dr. Noel Murray, December 3, 2014). However, the discovery of a BSE-infected Canadian cow in February 2015 - a cow born in 2009-brings into question the adequacy of Canada's current and past BSE control measures. When considering Canada's policies, we must ask whether the agencies involved adequately assessed, managed, and communicated the risks that BSE posed to the country's neurological health.

In this article, we have argued that Canadian policiesinterpreted in their proper historical and scientific contexts-have failed to meet the government's responsibility to protect Canadians. Specifically, Canadian policies have failed to recognize the implicit public health implications of managing BSE, which were well-established by the mid-1990s.

We have argued that policies surrounding BSE surveillance, limitations to rendering, and the control of SRMs have lagged behind advances in scientific knowledge. Although surveillance for BSE is assuredly complex from economic, political, and veterinary perspectives, voluntary surveillance in a punitive environment is unlikely to produce an accurate picture of disease rates. In a 2002 report, The World Health Organization advocated for active surveillance as an important risk control measure. ${ }^{73} \mathrm{We}$ cannot conclude from current practices that reliable estimates of BSE incidence are available. In short, the absence of evidence does not imply the evidence of absence. Although the rendering of cattle into human and animal feed is now greatly restricted, we are disappointed that it took until 2007 for such measures to be fully implemented when the potential role of rendering in the spread of BSE was well known at least 13 years earlier. Finally, the restriction of SRMs from the human food chain is likely the single most important measure to prevent the spread of BSE from cattle to humans, though it took ten years after the nation's first case of BSE for such a policy to be implemented. Questions surrounding the reliability of surveillance mechanisms and the control of rendering means that even a ban on SRMs may not prevent human exposure to BSE.

We contend that the discovery of the first BSE-positive cow in 1993 might have prompted the initiation of an active surveillance system, the termination of rendering, and the elimination of SRM from the human food chain. At that point, it was known that BSE existed in nervous and lymphoreticular tissue and that it had been disseminated by rendering; moreover, concerns about the spread of BSE to humans were widespread, if not confirmed. By restricting rendering and banning SRMs in human food, the risk of human disease could have been drastically reduced and the spread of animal disease would have been significantly limited. These measures, undertaken at that point in time, could have prevented the spread of BSE among Canadian cattle and would have prevented the possibility of human exposure. The adoption 
of such sweeping policies would have reflected a significant advance over British management, in accord with advances in scientific knowledge. And yet, such measures were not put in place.

As in Britain two decades before, it would appear that Canadian measures focused on BSE as an agricultural and veterinary issue first and foremost, rather than as a public health issue. And although such a stance may have been defensible up to 1996, the very real human health implications of BSE were firmly established thereafter. Fundamentally, the economic consequences that have befallen countries with BSE-affected cattle are only to a very limited extent a reflection of veterinary and agricultural issues. Raymond Bradley's original report from 1986 identified BSE as an animal disease that might be transmitted to humans with devastating consequences. It is because of these consequencesfully realized in the form of VCJD - that the economic effects of BSE are so severe. However, Canadian policy toward BSE since 1990 has generally failed to acknowledge the primary public health dimension of BSE. At least as early as 1996, authorities should have known that BSE was a health risk and hence an economic risk, too; the necessity of control measures should have been clear. However, the documents, rhetoric, and policies we have analyzed demonstrate a consistent tendency to downplay or altogether ignore the public health risks of BSE when politically inopportune.

Physicians are used to dealing with issues of risk in daily practice, and to some degree have adopted the practices of the "precautionary principle:" namely, that if a very concerning diagnosis is entertained, though not yet confirmed, it should be treated it as if it is present until there are assurances to the contrary. It is on the basis of this type of logic that patients with suspected meningitis receive empiric antibiotics while awaiting the results of the lumbar puncture, for example. And it is perhaps because we are familiar with this type of thinking as well as with the devastation of prion diseases that the practices of Canadian and British governments toward BSE in this period appear so inadequate.

This article has sought to complete a largely descriptive project: namely, to identify the policies implemented by the Canadian government toward BSE and to contextualize them from a historical and scientific perspective. To perform a thorough analysis of all the psychological and political factors affecting individual decision-making surrounding BSE goes beyond the scope of this article. However, we might begin to explore the rationale behind the practices and policies undertaken in Canada during the years 1990 to 2014. Unlike in Britain, where an antiregulatory ideology advocated by the Conservatives appears to have influenced BSE policy, a more liberal political philosophy existed in Canada during much of the period in question. The costs associated with implementing more extensive BSE control measures would likely have figured into the logic of politicians and bureaucrats, though these costs would have been unlikely to reach the billions of dollars that were ultimately lost because of BSE. Sympathy for Canadian cattle producers and the agricultural industries may have played a part in policy-making, though any sympathy that privileges the health of an industry over the health of the nation must be considered misplaced. Ignoring the public health implications of BSE and simply hoping the problem might go away also reflects a very human albeit unsatisfactory regulatory response. As Miller argues, science policy is never entirely scientific or entirely political.
Rather, decision-making in instances such as this one is appropriately complex and warrants further study.

Since the implementation of the SRM ban in 2003 and the extended feed ban in 2007, the number of cattle testing positive for BSE has declined significantly, such that Canada was preparing to apply for status as a "negligible risk" country under the terms of the OIE. That "negligible risk" status would have meant wide-ranging economic advantages for Canadian cattle producers and exporters. However, the discovery of the latest case of BSE in Alberta in February 2015 makes any such application impossible. One case of BSE, identified by current measures, does not guarantee an epizootic. However, it suggests that assurances about the success of current policies are perhaps overstated. If the rendering of cattle into cattle feed has truly been abandoned, and if BSE is not endemic to the Canadian herd, how could a native cow born in 2009 have acquired the disease? Recent discussions have focused on "feed-related" issues, suggesting that the cow may have consumed feed produced before the 2007 enhanced ban or produced after 2007 but in violation of the ban. ${ }^{74}$ If true, this finding supports our contention that Canadian policies have been implemented incompletely and in a delayed fashion, with limited surveillance. The latest affected cow was born on the same farm as a cow that had tested positive in 2010, which also suggests noncompliance with the feed ban. ${ }^{75}$ An alternative explanation is to suggest that BSE may arise by other means of contamination, or may occur de novo among Canadian cattle at a given spontaneous rate, much like sporadic CJD in humans. Therefore, it would appear premature to conclude that BSE (and with it the risk of vCJD) is a thing of Canada's past. ${ }^{76}$ If the events of February 2015 are any indication, BSE remains very much an issue in Canada's present.

\section{Disclosures}

The authors have no relevant conflicts of interest.

\section{ACKNOWLedgments ANd Funding}

M.S. is currently funded by a Junior Research Award from the Department of Medicine, University of Ottawa. He has previously received funding from the Ottawa Hospital Research Institute and Alberta Innovates Health Solutions.

\section{REFERENCES}

1. Canadian Food Inspection Agency. Canada's food inspection agency confirms bovine spongiform encephalopathy (BSE) in Alberta [Internet]. [updated 2015 Feb 20; cited 2015 Mar 20]. Available from: http://www.inspection.gc.ca/animals/terrestrial-animals/ diseases/reportable/bse/cfia-confirms-bse-in-alberta/eng/14237972 48015/1423797327027.

2. Smith PG. The epidemics of bovine spongiform encephalopathy and variant Creutzfeldt-Jakob Disease: current status and future prospects. Bull WHO. 2003;81:123-30.

3. CBC News. Mad cow case in Alberta won't harm exports, officials say [Internet]. [updated $2015 \mathrm{Feb} 13$; cited $2015 \mathrm{Mar} 20$ ]. Available from: http://www.cbc.ca/news/canada/calgary/mad-cow-case-inalberta-won-t-harm-exports-officials-say-1.2955910.

4. Shamy MCF. While England Ate: Government and the Risks of BSE, 1979-1996, Proceedings of the 21st Calgary History of Medicine Days. Cambridge, UK: Cambridge Scholars Publishing (in press).

5. Vossen P. Oral exposure of humans to the BSE agent: infective dose and species barrier. Scientific Steering Committee, European 
Commission. [published online 2000 March 3; cited 2015 May 18]. Available from: http://ec.europa.eu/food/fs/sc/ssc/out71_en.pdf.

6. Rhodes R. Deadly feasts: tracking the secrets of a terrifying new plague. New York: Simon \& Schuster; 1997.

7. Lanska DJ. The mad cow problem in the UK: risk perceptions, risk management, and health policy development. J Pub Health Pol. 1998;19:160-83.

8. Yam P. The pathological protein: mad cow, chronic wasting, and other deadly prion diseases. Heidelberg: Copernicus; 2003.

9. Cummings L. Rethinking the BSE crisis: a study of scientific reasoning under uncertainty. London, UK: Springer; 2010.

10. Hueston WD. BSE and variant CJD: emerging science, public pressure and the vagaries of policy-making. Prevent Veterinary Med. 2013;109:179-84.

11. Philips L, Bridgeman J, Ferguson-Smith M. The BSE inquiry report. London, UK: Her Majesty's Stationery Office; 2000.

12. Will RG, Ironside JW, Zeidler M, et al. A new variant of CreutzfeldtJakob disease in the UK. Lancet. 1996;347:921-5.

13. Almond J, Pattison J. Human BSE. Nature. 1997;389:437-8.

14. Woods A. The construction of an animal plague: foot and mouth disease in nineteenth-century Britain. Soc Hist Med. 2004;17: 23-39.

15. Woods A. Why slaughter? The cultural dimensions of Britain's foot and mouth disease control policy, 1892-2001. J Agric Environ Ethics. 2004;17:341-62.

16. Jacob M, Hellström T. Policy understanding of science, public trust and the BSE-CJD crisis. J Haz Mat. 2000;78:303-17.

17. Leiss W, Tyshenko MG, Krewski D, et al. Managing the risks of BSE: a Canadian perspective. Int $J$ Risk Ass Manage. 2010;14:381-436.

18. Von Zwanenberg P, Millstone E. Mad cow disease 1980s-2000: how reassurances undermined precaution. in Haeremoës P. The precautionary principle in the $20^{\text {th }}$ century: late lessons from early warnings. London, UK: Earthscan; 2002.

19. MacKnight C, Rockwood K. Bovine spongiform encephalopathy and Creutzfeldt-Jakob disease: implications for physicians. CMAJ. 1996;155:529-36.

20. Wilson K, Hébert PC, Laupacis A, Dornan C, Ricketts M, et al. A policy analysis of major decisions relating to Creutzfeldt-Jakob disease and the blood supply. CMAJ. 2001;165:59-65.

21. Wolfe RD. Where's the beef? Law, institutions and the Canada-U.S. border. In: Courchene TJ, Savoie DJ, Schwanen D, editors. Thinking North America, No. 6: The Art of the State, Volume 2. Montreal: Institute for Research on Public Policy; 2005. p. 69-98.

22. Le Roy D, Klein K. Mad cow chaos in Canada: was it just bad luck or did government policies play a role? Can Pub Pol. 2005;31: 381-99.

23. Leiss W, Nicol A-M. A tale of two food risks: BSE and farmed salmon in Canada. J Risk Res. 2006;91:891-910.

24. Charlebois S. A conceptual comparative analysis between the British and the Canadian mad cow crisis: the cost of learning [Internet]. Regina (SK): Saskatchewan Institute of Public Policy; 2005. [cited 2015 Mar 16]. Available from: http://www.publications. gov.sk.ca/details.cfm?p=11966.

25. Moens A. Mad cow: a case study in Canadian-American relations. Canada: Fraser Institute Digital Publication; March 2006.

26. Oliver DH, Fairbairn J. The BSE crisis-lessons for the future. Senate of Canada: Standing Senate Committee on Agriculture and Forestry; 2004 May.

27. The National CJD Research and Surveillance Unit. CreutzfeldtJakob disease in the UK (By calendar year) [Internet]. [updated 2015 Feb 2; cited 2015 Mar 18]. Available from: http://www.cjd. ed.ac.uk/documents/figs.pdf.

28. Aldy JE, Viscusi WK. Risk regulation lessons from mad cows. Faculty Research Working Paper Series, Harvard University Kennedy School of Government [Internet]. 2013 Nov [cited 2014 Dec 3]; RWP13-047:[63 p.].Available from: https://research.hks. harvard.edu/publications/workingpapers/citation. aspx $?$ PubId $=91$ 69\&type $=$ FN \&PersonId $=255$.

29. Miller D. Risk, Science and policy: definitional struggles, information management, the media and BSE. Soc Sci Med. 1999;49:1239-55.
30. Prusiner SB, Collinge J, Powell J, et al. editors Prion diseases of humans and animals. Chichester, UK: Ellis Horwood Ltd.; 1992.

31. Ellison D, Love S, Chimelli L, Harding BN, Lowe JS, Vinters HV, et al. Neuropathology: a reference text of CNS pathology. 2nd ed. Edinburgh: Mosby, 2004.

32. Armstrong RA, Cairns NJ, Ironside JW, Lantos JL. Size frequency distribution of prion protein (PrP) aggregates in variant Creutzfeldt-Jakob disease (vCJD). J Neural Transm. 2005;112: 1565-73.

33. Waldman M, Lamb M. Dying for a hamburger: modern meat processing and the epidemic of Alzheimer's disease. Toronto, Canada: McClelland \& Stewart; 2004.

34. Waldman M, Lamb M. Dying for a hamburger: modern meat processing and the epidemic of Alzheimer's disease (brief article) (book review). Booklist. 2005;101:1886.

35. Mcllroy A, Picard A. Burger theory lacks meat [dying for a hamburger]. Globe and Mail. 2004 May 1; Sect. F:9.

36. Geschwind M. Rapidly progressive dementia: prion diseases and other rapid dementias. Continuum: Lifelong learning in Neurology; 2010;16:31-56.

37. Mastrianni JA. The genetics of prion diseases. Genet Med. 2010;12:187-95.

38. Public Health Agency of Canada. Creutzfeldt-Jakob disease [Internet]. [updated 2015 Jan 31; cited 2015 Mar 16]. Available from: http:// www.phac-aspc.gc.ca/hcai-iamss/cjd-mcj/cjdss-ssmcj/stats-eng. php.

39. Bruce ME, Will RG, Ironside JW, et al. Transmissions to mice indicate that 'new variant' CJD is caused by the BSE agent. Nature. 1997;389:498-501.

40. Hill AF, Desbruslais M, Joiner S, et al. The same prion strain causes vCJD and BSE. Nature. 1997;389:448-526.

41. Brown DA, Bruce ME, Fraser JR. Comparison of the neuropathological characteristics of bovine spongiform encephalopathy (BSE) and variant Creutzfeldt-Jakob disease (vCJD) in mice. Neuropathol Appl Neurobiol. 2003;29:262-72.

42. Ritchie DL, Boyle A, McConnell I, et al. Transmissions of variant Creutzfeldt-Jakob disease from brain and lymphoreticular tissue show uniform and conserved bovine spongiform encephalopathyrelated phenotypic properties on primary and secondary passage in wild-type mice. J Gen Virol. 2009;90:3075-82.

43. Buschmann A, Groschup MH. Highly bovine spongiform encephalopathy-sensitive transgenic mice confirm the essential restriction of infectivity to the nervous system in clinically diseased cattle. J Infect Dis. 2005;192:934-42.

44. Warden J. When MPs chicken out over beef. BMJ. 1996;312:1502.

45. McKee M, Roberts JA, Lang T. Government policy has failed. BMJ. 1996;312:1038.

46. Carr-Brown J, Boztas S. A culture of secrecy that risked our lives. The Times (London). 2000 Oct 29; features.

47. Haines RJ. From farm to fork: a strategy for meat safety in Ontario. Report of the Meat Regulatory and Inspection Review. Province of Ontario. Canada. 2004.

48. Bruce M, Will RG, Ironside JW, et al. Transmissions to mice indicate that 'new variant CJD' is caused by the BSE agent. Nature. 1997;389:498-501.

49. Charlebois S. A conceptual comparative analysis between the British and the Canadian mad cow crisis: the cost of learning [Internet]. Regina (SK), Canada: Saskatchewan Institute of Public Policy; 2005. [cited 2015 Mar 16]. Available from: http://www.publica tions.gov.sk.ca/details.cfm?p=11966.

50. Canada Food Inspection Agency. Overview of Canada's BSE Safeguards [Internet]. [updated 2012 Mar 21; cited 2015 Mar 5]. Available from: http://www.inspection.gc.ca/animals/terrestrialanimals/diseases/reportable/bse/safeguards/eng/1363896195473/ 1363896681768.

51. Canada Food Inspection Agency. Canada's protocols for BSE surveillance [Internet]. [updated 2012 Dec 27; cited 2015 Mar 5]. Available from: http://www.inspection.gc.ca/animals/terrestrialanimals/diseases/reportable/bse/enhanced-surveillance/protocols/ eng/1356653159068/1356653329490.

52. World Organisation for Animal Health. Prevention and control [Internet]. [cited 2015 Mar 5]. Available from: http://www.oie.int/ animal-health-in-the-world/bse-portal/prevention-and-control/. 
53. Canada Food Inspection Agency. National BSE Surveillance Reimbursement Program [Internet]. [updated 2012 Dec 27; cited 2015 Mar 5]. Available from: http://www.inspection.gc.ca/ animals/terrestrial-animals/diseases/reportable/bse/enhanced-sur veillance/reimbursement/eng/1356644370690/1356645004073.

54. Mussel A, Grier K, Schmidt C, et al. Cost-benefit analysis of voluntary BSE testing of cattle [Internet]. Guelph (ON): George Morris Centre; 2011 Jan. [cited 2015 Mar 5]. Available from: http://prioninstitute.ca/forms/BSE\%20Testing\%20Final-revised $\% 20 \% 20$ Plus\%20App\% 20C\%20AM\%20Mar\%2029.pdf.

55. Alberta Farmer Express. As pain from BSE fades, Canada struggles on testing commitment [Internet]. 2014 Nov 17 [cited 5 Mar 2015]. Available from: http://www.albertafarmexpress.ca/2014/ 11/17/as-the-pain-from-bse-fades-canada-struggles-to-meet-test ing-commitment/.

56. Dunn FJ. Report of the Auditor General on the Alberta government's BSE-related assistance programs. Edmonton $(\mathrm{AB})$ : Office of the Auditor General; 2007 July. Report No.: ISBN0-7785-3703-X.

57. Canadian Cattlemen's Association. BSE documents [Internet]. c2013 - [cited 2014 Dec 3]. Available from: http://www.cattle.ca/ market-access/market-access-strategy/bse/bse-documents/.

58. Canada Food Inspection Agency. BSE Enhanced Surveillance Program [Internet]. [updated $2015 \mathrm{Feb} 17$; cited 2014 Jun 27]. Available from: http://www.inspection.gc.ca/animals/terrestrialanimals/diseases/reportable/bse/enhanced-surveillance/eng/1323 992647051/1323992718670.

59. Forge F, Fréchette J-D. Mad cow disease and Canada's cattle industry. Parliamentary Information and Research Service. July 12, 2005.

60. Anderton B, Collinge J, Powell J, Prusiner SB. An introduction to prion research. In: Prusiner SB, ed. Prion diseases of humans and animals. Chichester, UK: Ellis Horwood Ltd., 1992. p. 1-4.

61. Labreque J, Charlebois S. Conceptual links between two mad cow crises: the absence of paradigmatic change and policymaking implications. Int Food Agribus Rev. 2006;9:1-29.

62. Carlberg JG, Brewen DG. Managing an industry in crisis: BSE in Canada. In: Proceedings of Southern Agricultural Economics Association annual meetings, Little Rock, AR, February 5-9, 2005. Minneapolis (MN): AgEcon Search, University of Minnesota; 2005. p.1-20.

63. CBC News. Mad cow in Canada: the science and the story [Internet]. [updated 2005 Aug 24; cited 2014 Jul 16]. Available from: http:// www.cbc.ca/news $2 /$ background/madcow.

64. Boyd A, Jardine C, Dreidger M. Canadian media representations of mad cow disease. J Toxicol Environ Health. 2009;72:17-8.
65. British Broadcasting Corporation. Canada admits mad cow test delays [Internet] [updated 2003 May 22; cited 2014 Dec 3]. Available from: http://news.bbc.co.uk/2/hi/americas/3050455.stm.

66. British Broadcasting Corporation [Internet]. John Gummer: Beef Eater; [updated 2000 Oct 11; cited 2014 Dec 3]. Available from: http://news.bbc.co.uk/2/hi/uk_news/369625.stm.

67. Canadian Food Inspection Agency. Food directorate policy on specific risk material in the food supply [Internet] [updated 2003 July 22; cited 2014 Dec 4]. Available from: http://www. hc-sc.gc.ca/fn-an/securit/animal/bse-esb/policy_srm-politique_mrseng.php.

68. Canadian Food Inspection Agency. About Canada's enhanced feed ban [Internet]. [updated 2015 Feb 19; Cited 2015 Mar 18]. Available from: http://www.inspection.gc.ca/animals/terrestrial-animals/diseases/reportable/bse/enhanced-feed-ban/eng/1424374475489/14243 74476208

69. Canada Communicable Disease Report. Variant Creutzfeldt-Jakob disease in a Canadian resident [Internet] [updated 2012 Nov 21; cited 2014 Jul 16]. Available from: http://www.phac-aspc.gc.ca/ ccdrw-rmtch/2011/ccdrw-rmtcs1011r-eng.php.

70. Wilson K, Hébert PC, Laupacis A, et al. A policy analysis of major decisions relating to Creutzfeldt-Jakob disease and the blood supply. CMAJ. 2001;165:59-65.

71. Blajchman MA, Goldman M, Webert KE, Vamvakas EC, Hannon J, Delage G.. Proceedings of a consensus conference: the screening of blood donors for variant CJD. Transfus Med Rev. 2004;18: 73-92.

72. Hewitt PE, LLewelyn CA, Mackenzie J, Will RG. Creutzfeldt-Jakob disease and blood transfusion: results of the UK Transfusion Medicine Epidemiological Review study. Vox Sanguinis. 2006;91:221-30.

73. World Health Organization. Understanding the BSE threat. Geneva: World Health Organization; 2002, P. 28.

74. Better Farming. Canada's newest BSE case is 'feed related' says Ontario's chief vet [Internet] [updated 2015 Feb 19; cited 2015 Mar 20]. Available from: http://www.betterfarming.com/online-news/ canada's-newest-bse-case-'feed-related'-says-ontario's-chief-vet60670.

75. Global News. Two cows born with BSE on same Alberta farm, says CFIA [Internet] [updated 2015 Feb 27; cited 2015 Mar 20]. Available from: http://globalnews.ca/news/1855898/two-cowswith-bse-born-on-same-alberta-farm-says-cfia/.

76. Brown C. Mad cow update: risk now limited. CMAJ. 2010;182: E729-30. 